\title{
Predicting hydrologic flows under climate change: The Tâmega Basin as an analog for the Mediterranean region
}

\author{
A.R. Fonseca *, J.A. Santos \\ Centre for the Research and Technology of Agro-environmental and Biological Sciences, CITAB, Universidade de Trás-os-Montes e Alto Douro, UTAD, 5000-801 Vila Real, Portugal
}

\section{H I G H L I G H T S}

- Warming and drying future trends are projected for the target basin.

- A climate-hydrological modelling coupled approach is implemented.

- The HSPF model flowrate simulations show high performance vs observed values.

- Annual mean flowrate is projected to decrease under climate change.

- Return periods for daily flowrates significantly increase.

\section{G R A P H I C A L A B S T R A C T}

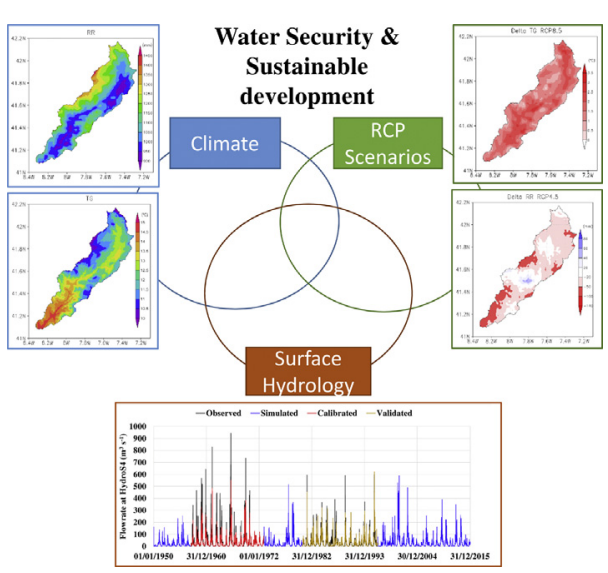

\begin{abstract}
A B S T R A C T
The potential effects of climate change on the hydrology of the Tâmega River basin, northern Portugal, are assessed by comparing simulated hydrologic scenarios derived from both observational climate databases for a recent past period (1950-2015) and EURO-CORDEX model simulations for the future (2021-2100). Future climate change scenarios are based on an ensemble of five climate model chain experiments and on two Representative Concentration Pathways (RCP4.5 and RCP8.5). Basin-mean annual temperatures are ca. $10 \%$ or $20 \%$ warmer than in recent past climate $\left(12.4^{\circ} \mathrm{C}\right)$ for RCP4.5 and RCP8.5, respectively. Furthermore, basin-mean annual precipitation decreases by approximately $8 \%$ or $13 \%$, when compared to recent past ( $1255 \mathrm{~mm}$ ). The Hydrological Simulation Program FORTRAN (HSPF) is applied to the historical data and to each of the five model simulations separately so as to simulate potential changes in flowrates. The model is calibrated and validated using 5 hydrometric stations, achieving satisfactory results regarding flowrate simulation. A reconstruction of flowrates within the entire river basin and over the historical period is accomplished, which is particularly useful when observed data is missing. The projected climate change impacts on annual flowrates reveal a decrease from $18 \%$ to $28 \%$ relative to observations $\left(70.9 \mathrm{~m}^{3} \mathrm{~s}^{-1}\right)$. These findings provide valuable information for the future management and planning of water resources (water security) and can be largely generalized not only to other basins in Portugal, but also over most of Southern Europe and throughout the Mediterranean Basin, where significant warming and drying trends are widespread footprints of climate change.
\end{abstract}

(C) 2019 Published by Elsevier B.V.

\footnotetext{
* Corresponding author.

E-mail address: andre.fonseca@utad.pt (A.R. Fonseca).
} 


\section{Introduction}

Climate change effects are observed worldwide and are conspicuously manifested by significant changes in local statistical distributional properties of temperature and precipitation, among other atmospheric parameters, which also persist over time scales from decades to centuries (IPCC, 2007a, 2007b, 2013). It is widely accepted that human activities (anthropogenic radiative forcing resulting from exacerbated greenhouse gas emissions) have been driving noticeable impacts on global climate and, at least partially, explaining the observed global warming recorded since the pre-industrial era (Solomon et al., 2009).

In addition, according to the Intergovernmental Panel on Climate Change (IPCC) 5th Assessment Report, the projected average warming in Europe will be of $1.4-5.8{ }^{\circ} \mathrm{C}$ by the end of 2100 (Eisenreich et al., 2005; IPCC, 2014), despite the pronounced regional gradients in temperature trends. In many regions, these changes may be associated with considerable modifications in the atmospheric circulation, throughout a cascade of spatial scales, from the large to the micro scales, since an increase in temperature may e.g. result in enhanced evapotranspiration and changes in the precipitation patterns and regimes
(Nicholls et al., 1996). Further, the occurrence of extreme precipitation events is projected to increase, which suggests implications not only in surface runoff, but also reduced groundwater recharge and more frequent and stronger flooding events. Moreover, the duration, frequency and intensity of droughts are expected to strengthen (Bronstert, 2003; Todd et al., 2011). Some of the projected changes in the hydrological regimes can be indeed attributed to changes in weather and climate extremes, under a warmer atmosphere, as well as to modifications in evapotranspiration, due to changes in surface soil moisture, net radiation, atmospheric humidity or snow melting/accumulation (Eisenreich et al., 2005; Hattermann et al., 2007; Hattermann et al., 2015; Hattermann et al., 2008). Many watershed-scale modelling studies of the impacts of climate change on hydrology have shown a wide range of different results, depending on the specific location of the study area (Andréasson et al., 2004; Bae et al., 2008; Christensen et al., 2004; Eckhardt and Ulbrich, 2003; Frei et al., 2002; Fujihara et al., 2008; Graham, 2004; Hattermann et al., 2015; Loukas et al., 2002; Thodsen, 2007; Whitehead et al., 2018). Although it is widely accepted that in many tropical and mountainous regions there is a projected increase in the availability of water resources, as a result of increased
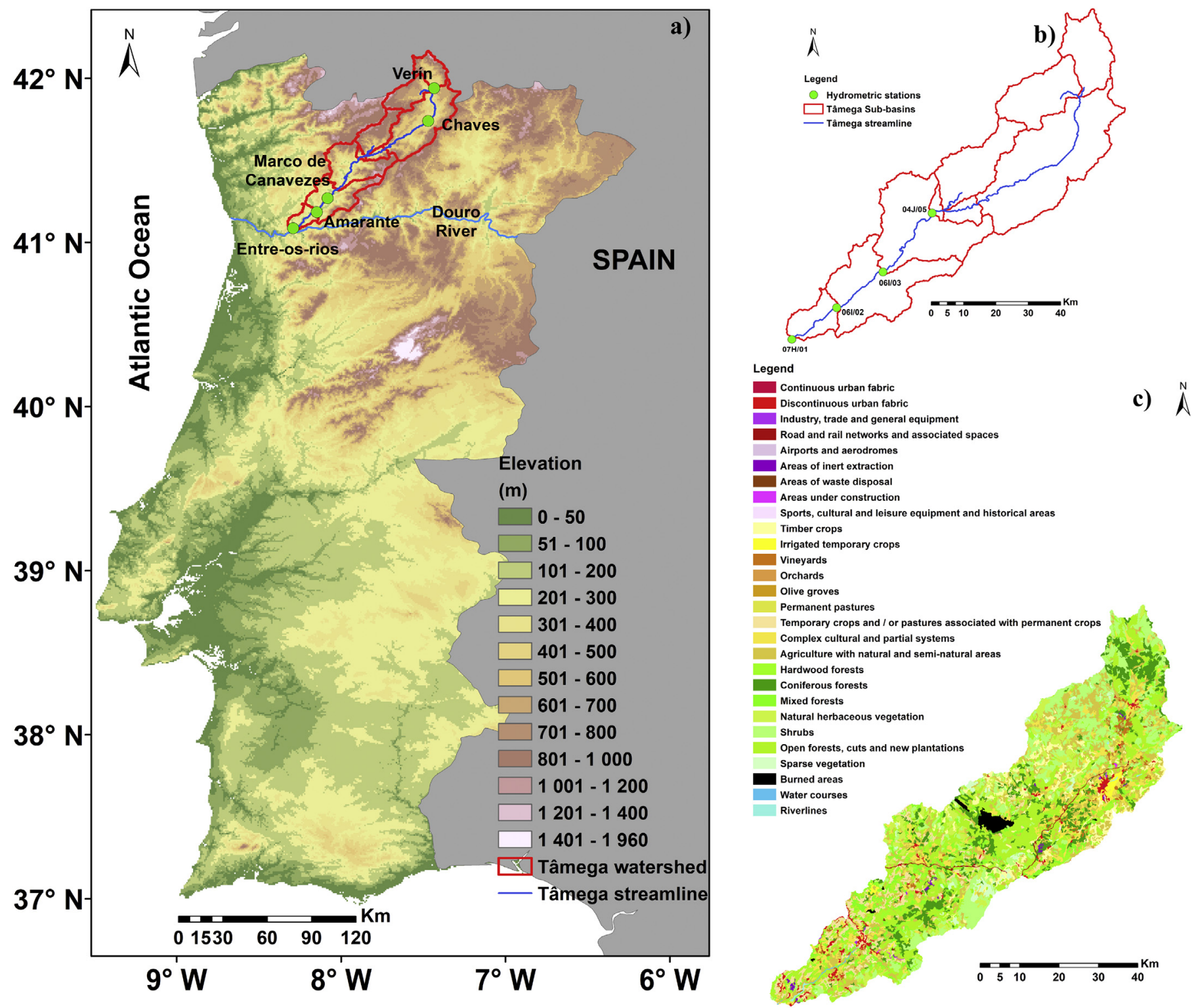

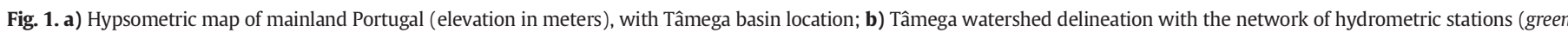
circles); c) COS2015 of Tâmega watershed. 
precipitation, this may aggravate flood risks. On the other hand, water availability may significantly decrease in some sub-humid and semiarid climates, such as in Mediterranean-type climates (Haas, 2002; Loizidou et al., 2016).

The aforementioned climate-driven changes may thereby have an important impact on regional water resources, such as in water availability, leading to a possible increase of groundwater exploitation, which may reach unsustainable levels in the near future, with adverse impacts on wetlands and several ecosystems (Boughariou et al., 2018; Crosbie et al., 2013; Me et al., 2018; Mortazavi-Naeini et al., 2015; Vrzel et al., 2019). Therefore, significant changes in the spatial and temporal availability of water resources, or in the general water balance, may potentially affect many socioeconomic sectors, such as agriculture, industry and urban development (Ali, 2018; Gebre et al., 2015; Mirza, 2003; Wagena et al., 2018; Whitehead et al., 2018), as well as regional/local ecosystem services. As such, achieving water security is, and will expectedly remain, a major challenge worldwide, while climate change is very likely to become a foremost constraint over the next decades.

To meet these new challenges, motivated by water security and resources management, the quantification of potential climate change impacts on hydrology at the watershed scale needs to be properly addressed, as regional scale studies are critical for an accurate impact assessment (Kabat et al., 2003; Krysanova et al., 2008; Varis et al., 2004). Hydrological modelling at the watershed scale not only allows a clearer representation of the available water resources and demand, but also provides indicator metrics of adaptation, vulnerability and risk. However, the climatic factor is one among several modifications that are expected to take place in the future. Others, such as changes in land cover and land use, economic structure systems and water demand, may also considerably influence water resources management in the future and should be considered to assemble realistic water resources scenarios (Costa et al., 2003; Ghaffari et al., 2010; Pervez and Henebry, 2015; Sahin and Hall, 1996). These impacts will require suitable and timely adaptation measures to cope with the foreseen changes in local climate, as well as in geographic, ecological, economic and social environments. The major source of uncertainty can be found in climate change projections, specifically owed to the formulation of the climate model and of its sensitivity to greenhouse gas forcing (Slingo and Palmer, 2011). Therefore, it is advisable to use an ensemble of different global and regional climate models to reduce the uncertainty associated with the model projections and to increase the robustness of the climate change signal.

For taking into duly consideration the uncertainty encompassed by the future scenarios, it is common practice to use climatic datasets generated by multi-model ensembles of regional climate models (RCMs), forced by global climate models (GCMs), as input to drive hydrological models (HMs) (Hattermann et al., 2015; Kling et al., 2012; Varis et al., 2004), i.e. GCM-RCM-HM chains. This approach allows a dynamic downscaling of the scenario information from the global scale to the basin scale. Hereof, an illustrative case study for the Tâmega River, a tributary of the Douro River, in Northern Portugal, is carried out. The present study presents the potential impact of future climate change on the Tâmega River hydrology and water availability. For this purpose, a hydrological model is calibrated and validated for the Tâmega River basin and, subsequently, applied to the climate change scenarios

Table 1

Integrated General Circulation Models (GCMs) with Regional Climate Models (RCMs) used to assess climate change impacts on Tâmega River hydrology.

\begin{tabular}{lll}
\hline GCMs & RCMs & Institution \\
\hline CNRM-CERFACS-CNRM-CM5 & CLMcom-CCLM4-8-17 & CLMcom \\
CNRM-CERFACS-CNRM-CM5 & SMHI-RCA4 & SMHI \\
MPI-M-MPI-ESM-LR & CLMcom-CCLM4-8-17 & CLMcom \\
MPI-M-MPI-ESM-LR & SMHI-RCA4 & SMHI \\
ICHEC-EC-EARTH & DMI-HIRHAM5 & DMI
\end{tabular}

produced by an ensemble of five different GCM-RCM model chains, under two different greenhouse gas emission scenarios (RCP4.5 and RCP8.5).

Similar findings should be expected for other river basins in Portugal, as well as in many other Southern European regions, as the climate change future projections reveal a strong spatial consistency over Southern Europe and the Mediterranean Basin (Gibelin and Déqué, 2003; Giorgi and Lionello, 2008). More specifically for Portugal, typical Mediterranean-climate conditions prevail, featuring autumn-winter rainy periods and spring-summer dry periods, thus showing a strong seasonality and irregularity in the precipitation regime and, as a result, in the hydrological cycle (Andrade et al., 2011; Santos et al., 2010). Climate change projections for Portugal show an increase in annual mean temperature, ranging from $2.3^{\circ} \mathrm{C}$ to $2.8^{\circ} \mathrm{C}$ (Yang et al., 2018), accompanied by a significant drying trend, with decreases in annual precipitation from -132 to $-58 \mathrm{~mm}$ (Fraga et al., 2018). Overall, future climates in Portugal are projected to become progressively warmer and drier, with a gradual strengthening of aridity and an inexorable decrease in water availability (Fraga et al., 2018; Mourato et al., 2014; Santos et al., 2017, 2018; Yang et al., 2018).

Along the previous lines, the main objectives of the present study are threefold: 1) to calibrate and validate a hydrological model within the target basin, thus allowing the simulation of hydrological parameters throughout the basin and during a recent past period, including the reconstruction of the time series over periods with missing data; 2 ) to develop future projections of hydrological parameters under different emission scenarios, which may be subsequently taken into account in decision-making processes regarding future water resource management and planning in Portugal; 3) the followed methodology can be extrapolated to other parts of Portugal to determine water security in other watersheds.

\section{Materials and methods}

\subsection{Study area}

The Tâmega River headspring is located in Spain, close to the northern Portuguese-Spanish border (Serra de San Mamede, at an elevation of $960 \mathrm{~m}$ amsl) and, after a few kilometers, it enters in Portugal in the "Norte" NUTS-2 region. It flows through the cities of Chaves, Amarante and Marco de Canavezes, flowing in the Douro River near Entre-osRios, with the river mouth at an elevation of $15 \mathrm{~m}$ amsl (Fig. 1a). Being one of the main tributaries of the Douro River, it covers an area of approximately $3317 \mathrm{~km}^{2}$ and has a total extension of nearly $145 \mathrm{~km}$. The main subsections of the watershed are also depicted in Fig. 1a. The Tâmega River basin is bounded by the Sousa (to the west) and Corgo (to the east) river basins, both subsidiaries of the Douro River, and by the Ave and Cávado river basins to the north.

Table 2

Statistical criteria values of the deviation of volumes (Dv), R-squared $\left(R^{2}\right)$ and NashSutcliffe coefficient of efficiency (E) for the calibration and validation of daily flowrate at the four hydrometric stations in Tâmega watershed.

\begin{tabular}{llll}
\hline & $\mathrm{Dv}(\%)$ & $\mathrm{R}^{2}(\%)$ & $\mathrm{E}$ \\
\hline Calibration & & & \\
HydroS1 (1957-1980) & -10.4 & 82.5 & 0.83 \\
HydroS2 (1985-2000) & 9.7 & 75.2 & 0.83 \\
HydroS3 (1955-1970) & -6.8 & 91.8 & 0.92 \\
HydroS4 (1988-2000) & -3.1 & 79.8 & 0.85 \\
Validation & & & \\
HydroS1 (1981-2011) & 10.3 & 71.9 & 0.71 \\
HydroS2 (2001-2011) & -9.9 & 88.3 & 0.85 \\
HydroS3 (1972-1987) & 5.6 & 71.7 & 0.72 \\
HydroS4 (2001-2014) & -9.4 & 85.7 & 0.89
\end{tabular}



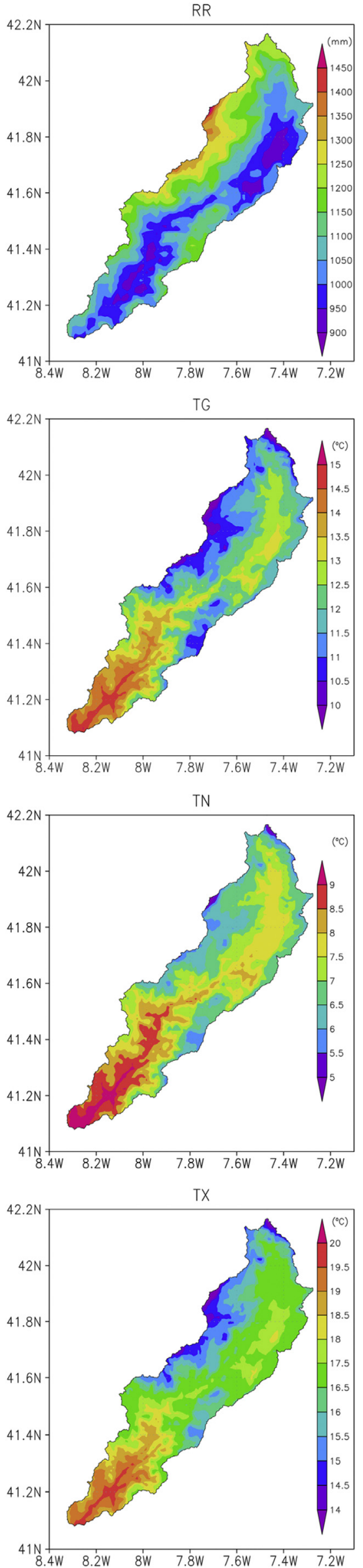
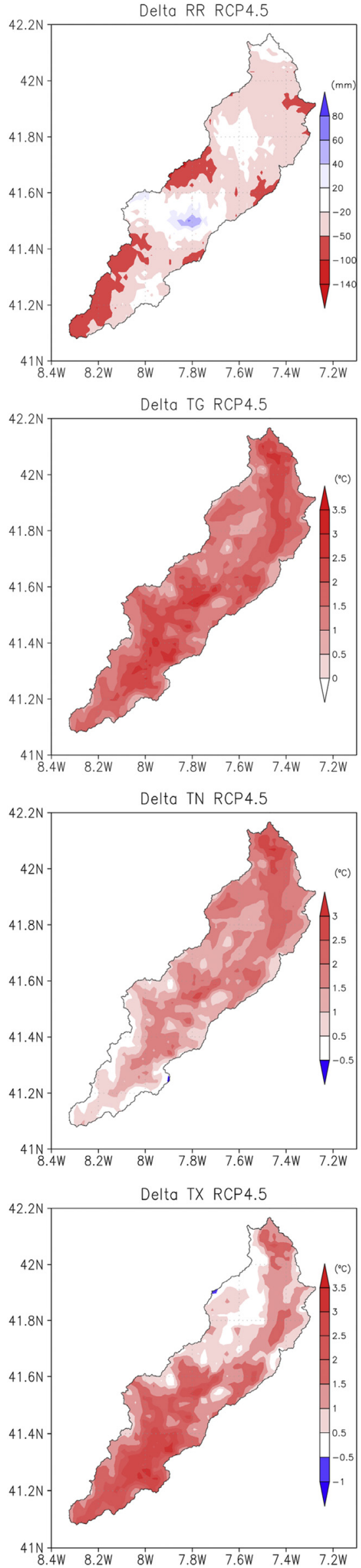
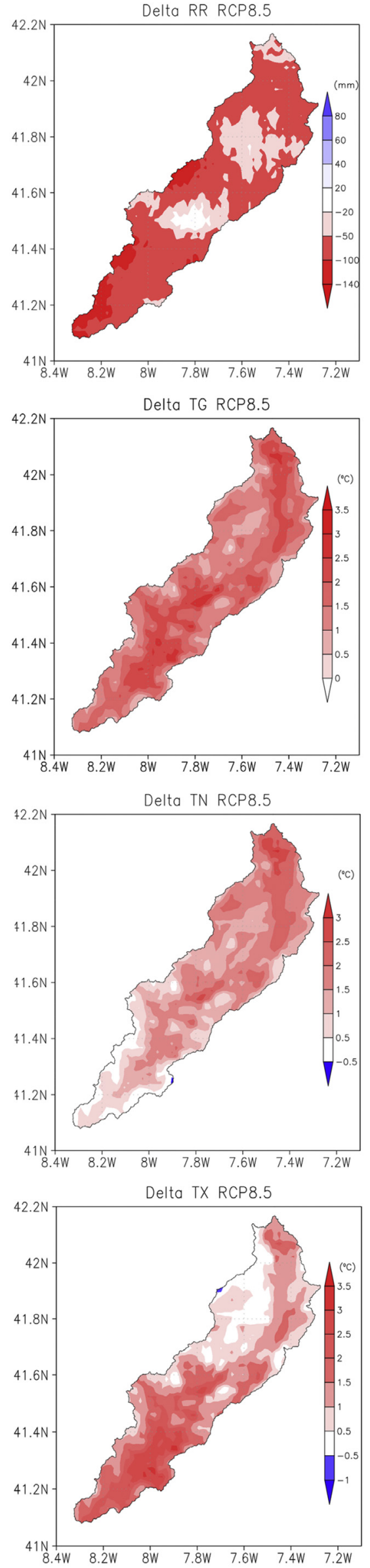


\subsection{Datasets}

\subsubsection{Historical dato}

Very high resolution $(\sim 1 \mathrm{~km})$ gridded daily mean, minimum and maximum temperatures over mainland Portugal (PT.TG.HRES, PT.TN. HRES and PT.TX.HRES) over the baseline period of 1950-2015 were retrieved for the grid points covering the Tâmega River catchment. The methodology followed to obtain these gridded datasets, their validation and characterization can be found in Fonseca and Santos (2018a).

Gridded daily precipitation totals at $\sim 20 \mathrm{~km}$ spatial resolution (PT02 database), supplied by the Portuguese Weather Service (Instituto Português do Mar e da Atmosfera - IPMA, www.ipma.pt), are available for Portugal over the period of 1950-2003 (Belo-Pereira et al., 2011). PT02 comprises a high number of homogenized weather station series over mainland Portugal, thus being particularly useful for the present study purposes, as hydrological models strongly rely on high-quality precipitation data. For the remaining period of 2004-2015, not available from PT02, the daily precipitation data were reconstructed following a simple statistical estimation methodology. The E-OBS gridded daily precipitation amounts (Haylock et al., 2008), which have been used in many previous studies of precipitation in Portugal (Fonseca and Santos, 2018a, 2018b; Fonseca et al., 2018b), were retrieved within the same geographical sector and bi-linearly interpolated to the PT02 spatial resolution. The E-OBS time series at each grid point were subsequently multiplied by the ratio between the annual precipitation of PT02 and E-OBS over their overlapping time period of 1950-2003. Overall, the correlation coefficients between the daily precipitation amounts in both datasets is very high ( $>0.90$ at all grid points), hinting at the high coherency between the two datasets and warranting the feasibility of this simple reconstruction approach. The resulting gridded precipitation dataset then comprises the total baseline period of 1950-2015 (PT.P. HRES henceforth). Gridded daily precipitation fields were then bilinearly interpolated (on latitude and longitude coordinates) to a $\sim 1 \mathrm{~km}$ grid resolution for the whole dataset covering mainland Portugal and were then retrieved within the Tâmega River catchment. Despite some uncertainties regarding precipitation interpolation at such a fine scale, this approach allows making use of the greater detail in the temperature data in the subsequent hydrological modelling.

Daily streamflow data (flowrates), collected at four hydrometric stations $(07 \mathrm{H} / 01,06 \mathrm{I} / 02,06 \mathrm{I} / 03,04 \mathrm{~J} / 05$, Fig. $1 \mathrm{~b})$, were obtained from the Sistema Nacional de Informação de Recursos Hídricos (SNIRH, www. snirh.pt). For the sake of readability, the station designations will be HydroS1 (04J/05), HydroS2 (06I/03), HydroS3 (06I/02) and HydroS4 $(07 \mathrm{H} / 01)$ henceforth. The flowrate series are available from 1957 to 2011 at station HydroS1, from 1985 to 2011 at station HydroS2, from 1955 to 1987 at station HydroS3 and from 1988 to 2014 at station HydroS4.

\subsubsection{EURO-CORDEX model simulations}

Climatic datasets from a five-member ensemble of GCM-RCM chain simulations (Table 1), produced within the framework of the EUROCORDEX project, were retrieved for the development of climate change projections (http://www.euro-cordex.net/). Gridded daily precipitation totals (RR), minimum (TN) and maximum (TX) 2-meter air temperatures were extracted for the future period of 2021-2100 (short-term: 2021-2040, mid-term: 2041-2070 and long-term: 2071-2100) over the study area, at a spatial resolution of $0.125^{\circ}$ latitude $\times 0.125^{\circ}$ longitude $(\sim 14 \mathrm{~km} \times 11 \mathrm{~km}$ in the study area) and under RCP4.5 and RCP8.5.

\subsubsection{CORINE Land Cover and digital elevation model}

A high resolution digital elevation model of $10 \mathrm{~m}$ spatial resolution was used to delineate the watershed (Fig. 1a). The CORINE Land Cover 2012 (CLC2012) raster data were retrieved from the European
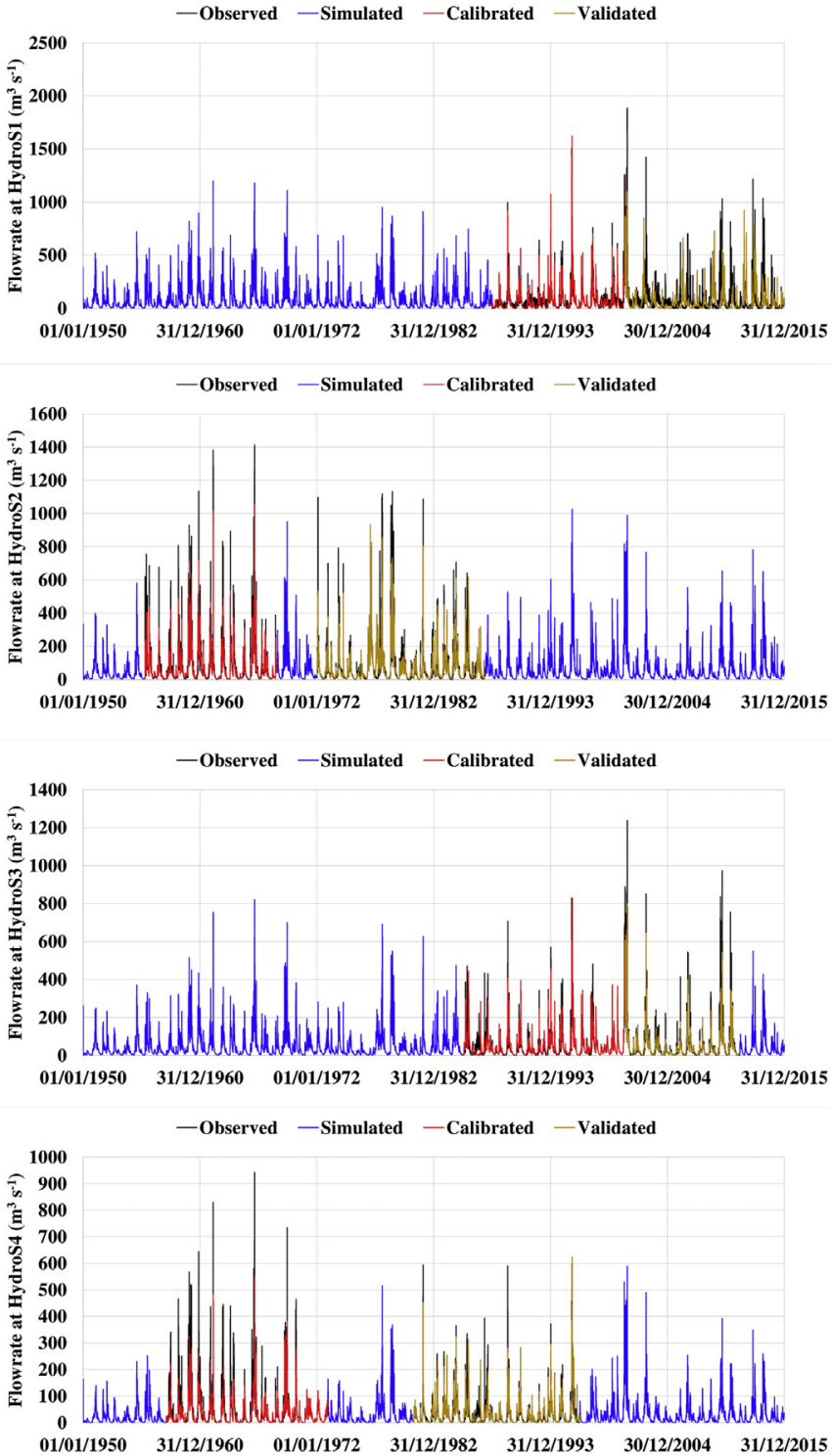

Fig. 3. Chronograms of the observed and HSPF simulated (calibrated and validated) daily mean flow rates at stations: (a) HydroS1; (b) HydroS2; (c) HydroS3 and (d) HydroS4 (see text and figure legends for details).

Environment Agency (EEA, http://www.eea.europa.eu). The corresponding land use classes within the Tâmega River basin are also shown in Fig. 1c.

\subsection{Hydrological model}

The climatic data were afterwards used as input in the Hydrological Simulation Program FORTRAN (HSPF) model so as to assess future daily flowrates at the four available hydrometric stations along the Tâmega River (Fig. 1b). This hydrological model is integrated in the multipurpose environmental analysis system Better Assessment Science Integrating Point and Non-point Sources (BASINS), which is designed to perform water quantity and quality based studies. HSPF is based on the original Stanford Watershed Model IV (Crawford and Linsley, 1966) and is an assemblage of three previously well-established models: Non-point Source Runoff Model (NPS) (Donigian and Crawford, 1976), Agricultural Runoff Management Model (ARM)

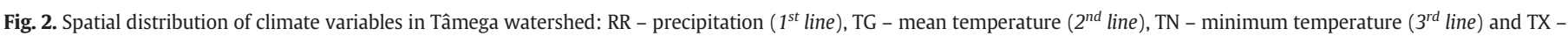
maximum temperature ( $4^{\text {th }}$ line). Historical data of 1950-2015 (left panel) and deltas derived for the period of 2021-2100 for scenarios RCP4.5 (mid panel) and RCP8.5 (right panel). 
(Donigian and Davis, 1978) and Hydrological Simulation Program (HSP) including HSP Quality (Donigian and Huber, 1991; Donigian et al., 1995). HSPF is a semi-distributed model that simulates water quantity and quality transport over spatially distributed areas within a given watershed (Bicknell et al., 2001). The application of HSPF to model water quantity and quality has been reported in several previous studies (Bergman et al., 2002; Fonseca et al., 2014, 2015, 2016, 2018a, 2018b; Fonseca and Santos, 2018b; Zhang et al., 2009). A guideline of hydrology and hydraulic parameters, along with the corresponding recommended value ranges (parameterizations), can be found in BASINS Technical Note 6 (Bicknell, 2000). The estimation of the potential evapotranspiration (PET) in HSPF is based on the Penman-Monteith equation (Penman, 1948) and on the method of Kohler et al. (1955). The PET time series are calculated within the Watershed Data Management Utility (WDMUtil, BASINS platform plugin), which is a tool for managing watershed modelling data (Hummel et al., 2001).

a)

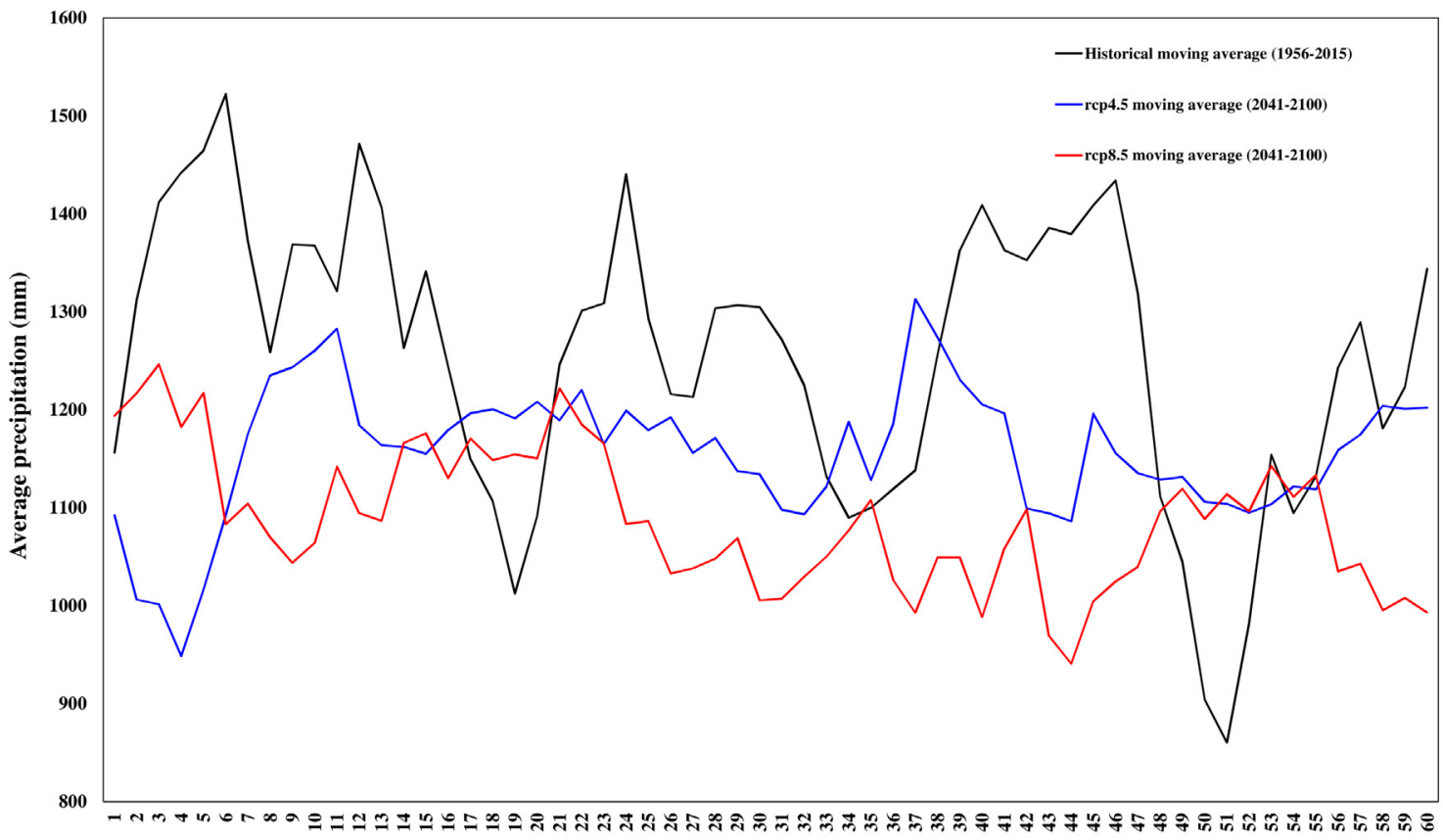

b)

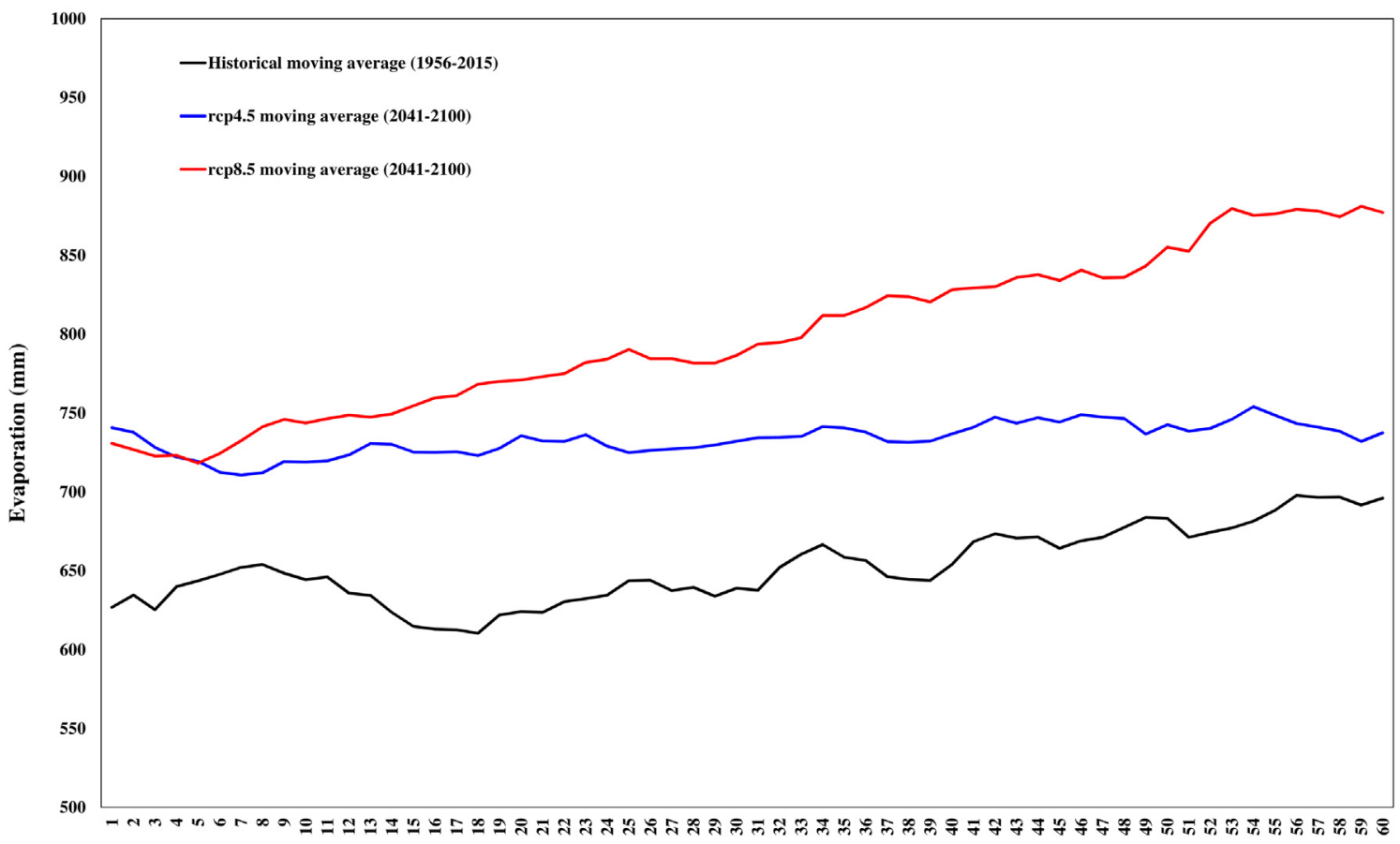

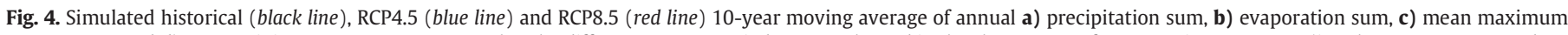

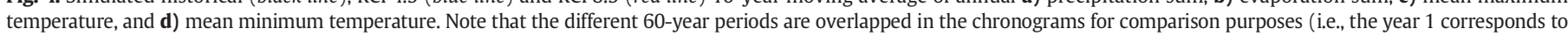
1956 or 2041 depending on the curve). 
c

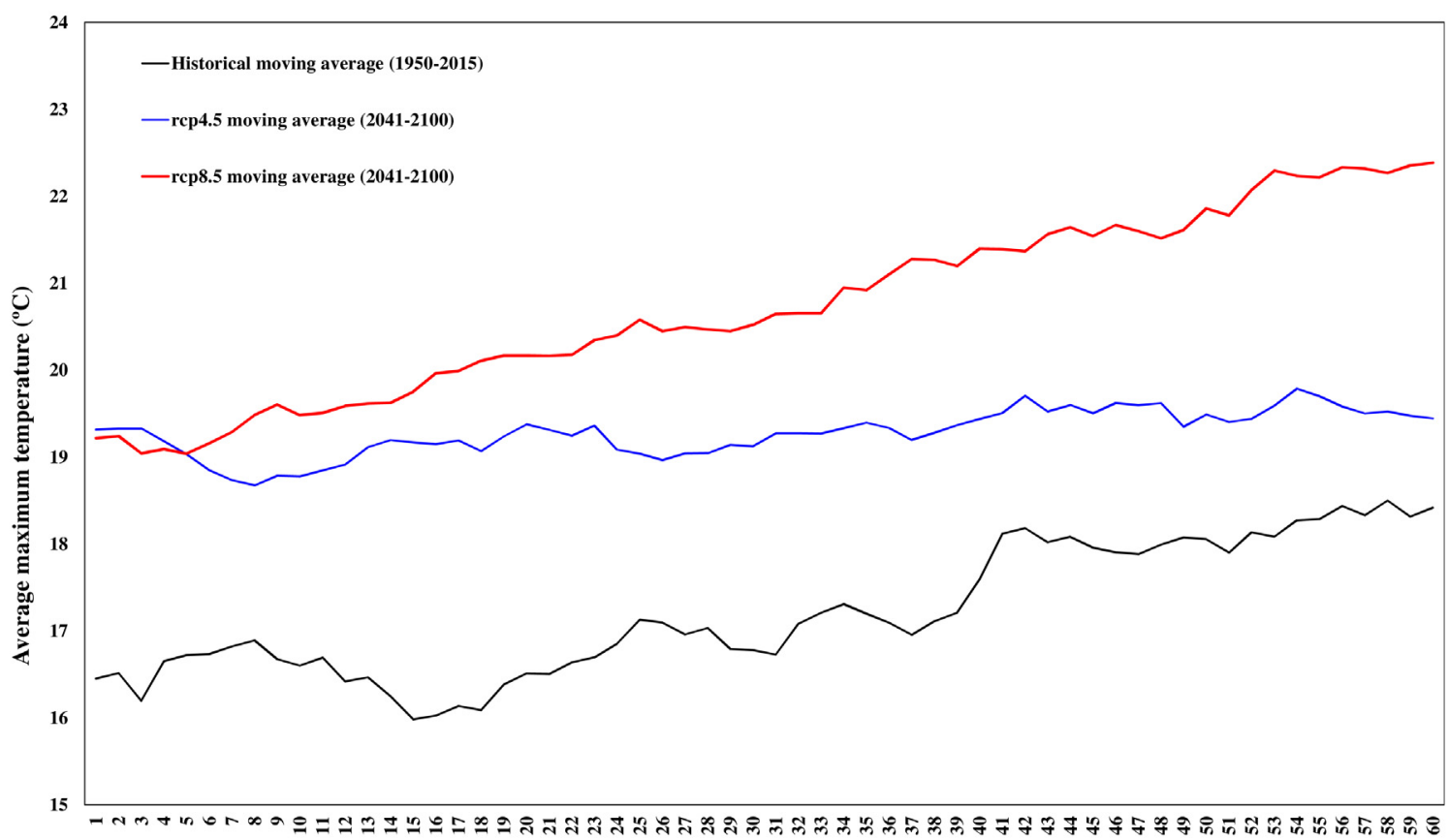

d

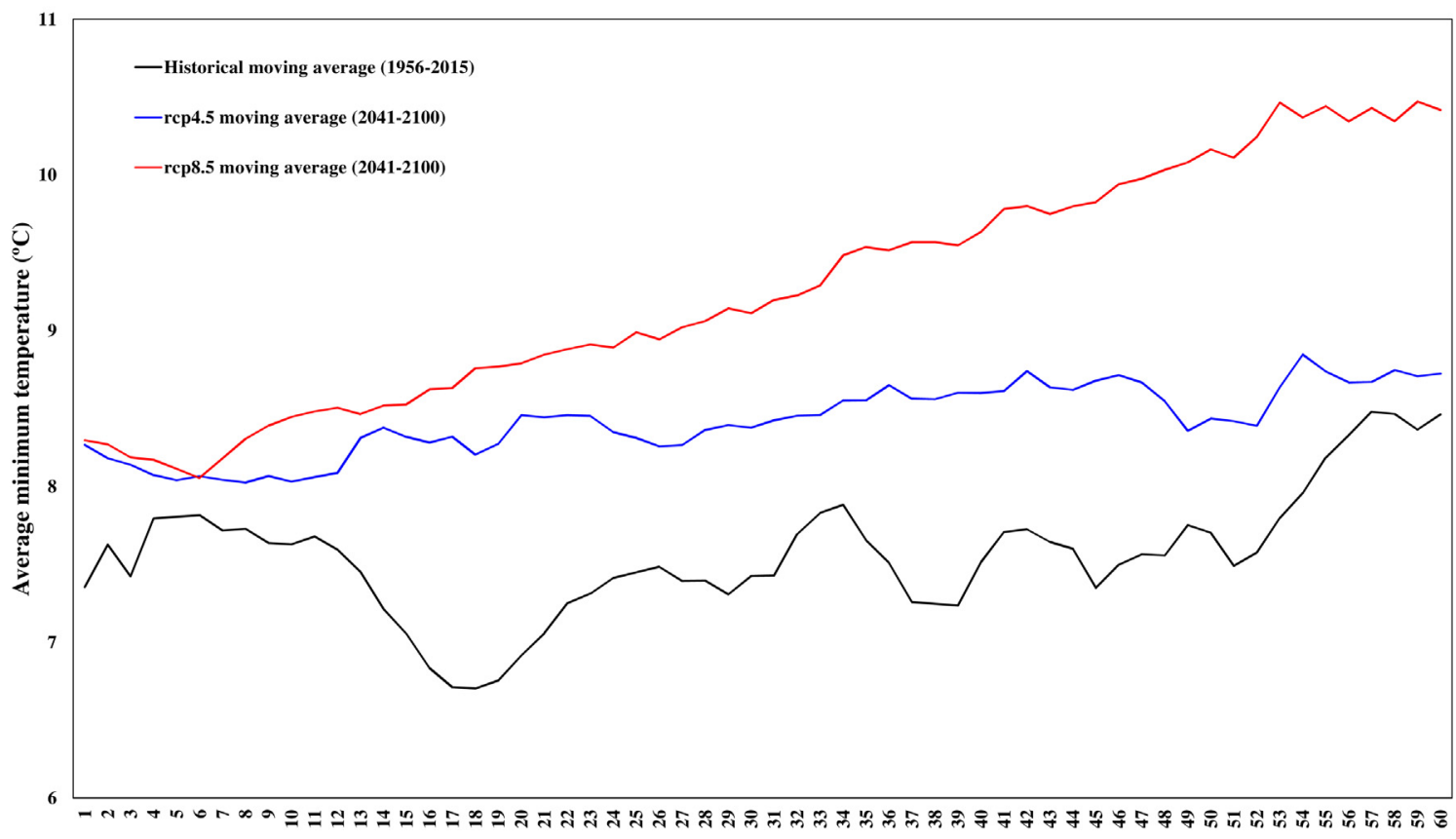

Fig. 4 (continued).

\subsection{Model calibration and validation}

Daily flowrates were calibrated and validated at four hydrometric stations with available data in the Tâmega watershed. Flowrate was calibrated for the following hydrological years 1957-1980, 1985-2000, 1955-1970 and 1988-2000 and validated for the hydrological years of 1981-2011, 2001-2011, 1972-1987 and 2001-2015 for the hydrometric stations HydroS1, HydroS2, HydroS3 and HydroS4, respectively. In view of the number of hydrological years with data available for both calibration and validation at each hydrometric station, it is reasonable to assume that the model incorporates the main hydrological features. The model validation was performed after its calibration goodness-offit was acceptable. The verification of the model performance was undertaken by three statistical metrics: Deviation Runoff $(D v)$, NashSutcliffe efficiency coefficient (E) (Nash and Sutcliffe, 1970) and the Coefficient of Determination $\left(R^{2}\right)$. 

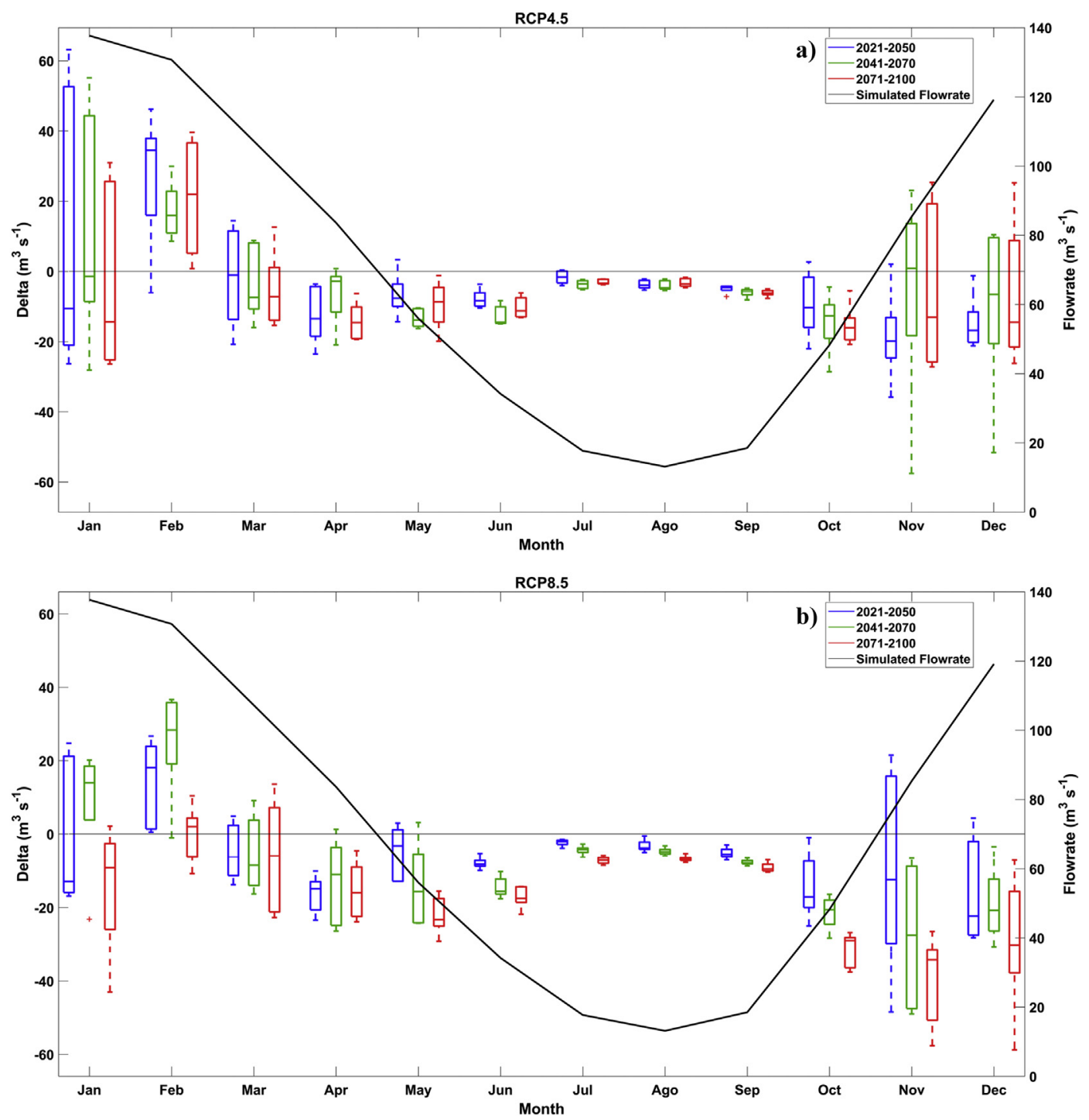

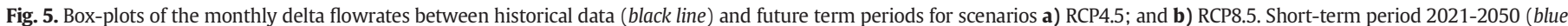
color), mid-term period 2041-2070 (green color) and long-term period 2071-2100 (red color).

\section{Results and discussion}

\subsection{Calibration and validation of the hydrological model}

Daily hydrographs for the recent-past period (1950-2015) are shown in Fig. 3. They reveal the information on the observed, calibrated and validated data as well as the reconstruction of the flowrates for the entire period. Despite the underestimation of the flowrate peaks by the model, mostly at the HydroS1 station, daily hydrographs at all hydrometric stations show quite satisfactory agreements between observed and simulated flowrates. This is confirmed by the daily values of the statistical criteria presented earlier for both the calibration and validation periods (Table 2). The deviation of volumes (Dv) varies from $-10.4 \%$ to $10.3 \%$, with the best simulation achieving $-3.1 \%$ at station HydroS4 (calibration). The R-Squared $\left(\mathrm{R}^{2}\right)$ values are always above $71 \%$, reaching the best simulation performance at station HydroS3 (91.8\%, calibration). Daily values of the Nash-Sutcliffe coefficient of efficiency are also very satisfactory, with values as high as 0.92 for calibration (HydroS3) and 0.89 for validation (HydroS4). The lowest value of 0.71 is obtained for the HydroS1 station. Hence, these results demonstrate a remarkably high performance of HSPF in simulating the daily flowrates at the Tâmega River basin, thus enabling its application under future climates. Daily calibration and validation hydrographs only for the period with observed data at the four hydrometric stations are shown in supplementary material (Fig. S1) for better analysis.

\subsection{Temporal variability of climate and flowrate}

The climate change signals (ensemble means in the future minus recent past) of the annual mean precipitation (RR), mean (TG), minimum (TN) and maximum (TX) air temperatures in the Tâmega River watershed, for the period of 2021-2100 and under both RCP scenarios, are depicted in Fig. 2. For the recent past period (1950-2015), precipitation varies spatially within the range of $900-1450 \mathrm{~mm}$, with the lowest values along the river streamline, as lower elevations are commonly associated with less rainfall. Overall, both RCPs show precipitation decreases over most of the watershed, particularly under RCP8.5 and in its southernmost section. Annual mean temperatures vary from 10 to $15^{\circ} \mathrm{C}$, with warmer temperatures at the River mouth (lowest elevation). The future scenarios show an increase of up to $3.5^{\circ} \mathrm{C}$ under RCP8.5. The spatial variability is very similar for both TN and TX (TN: $5-9{ }^{\circ} \mathrm{C}$; TX: $14-20^{\circ} \mathrm{C}$ ). For the future scenarios, strong upward trends are displayed, more pronounced for $\mathrm{TN}$ in the northern half of the basin (up to $3^{\circ} \mathrm{C}$ ) and for TX in its southern half (up to $3.5^{\circ} \mathrm{C}$ ), also accompanied by a noticeable increase along the river line. 
a)
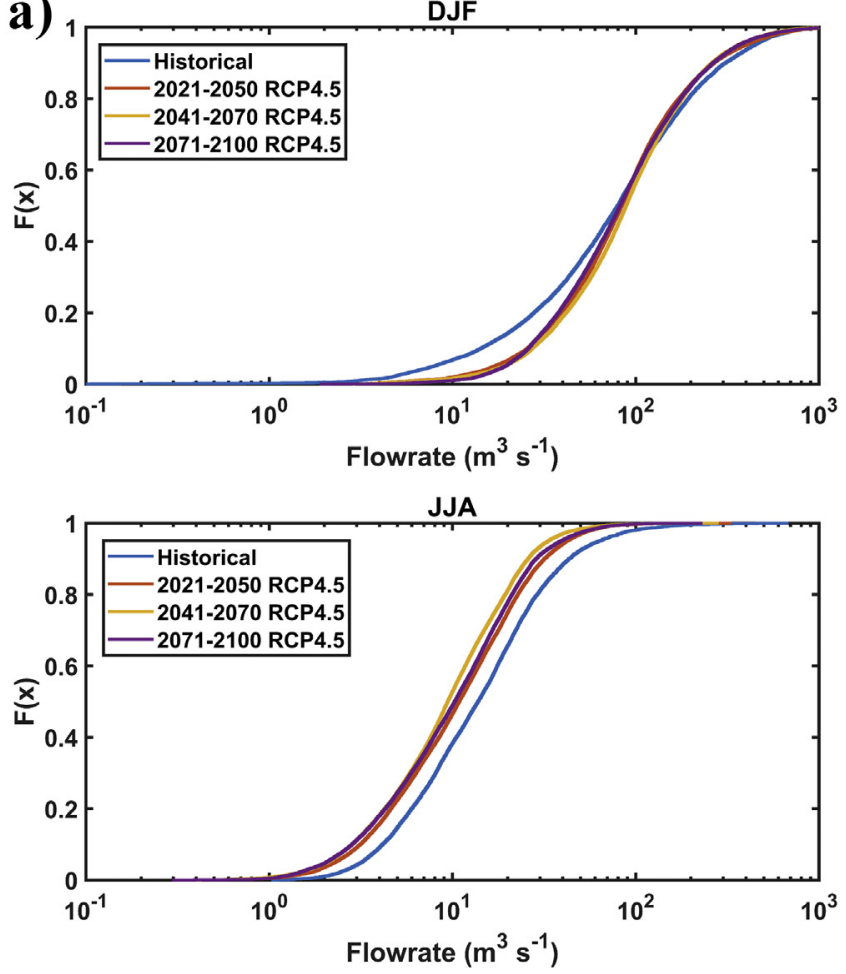

b)

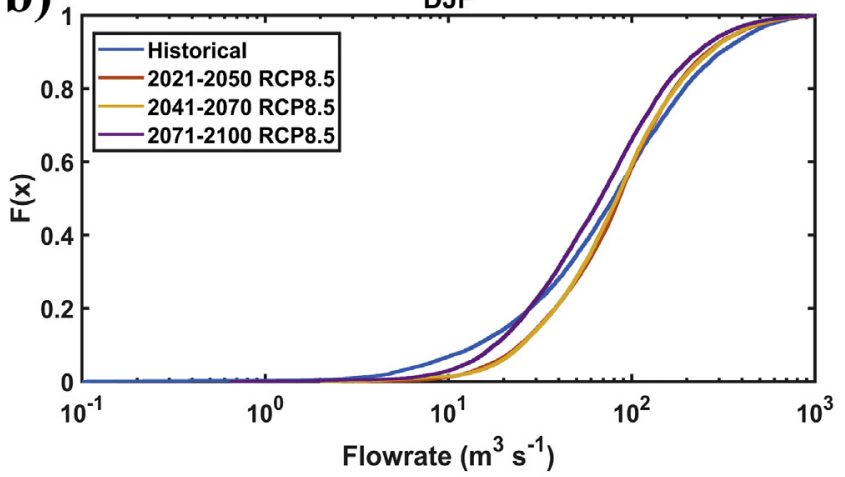

JJA

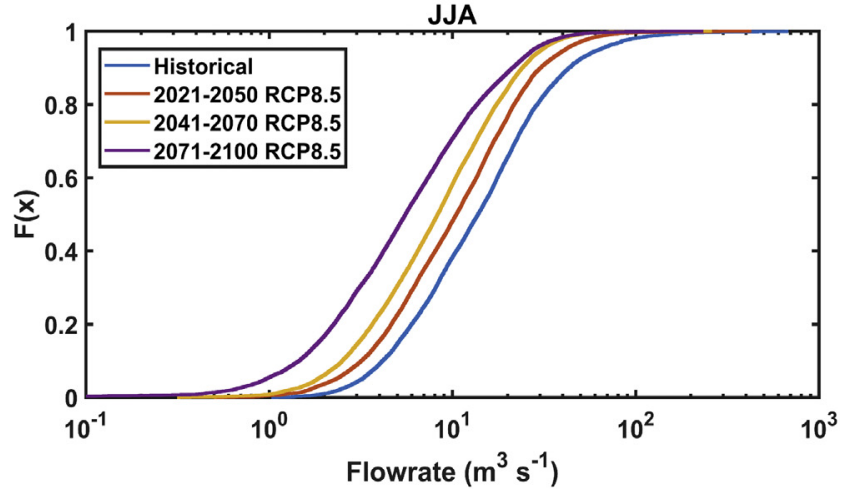

MAM

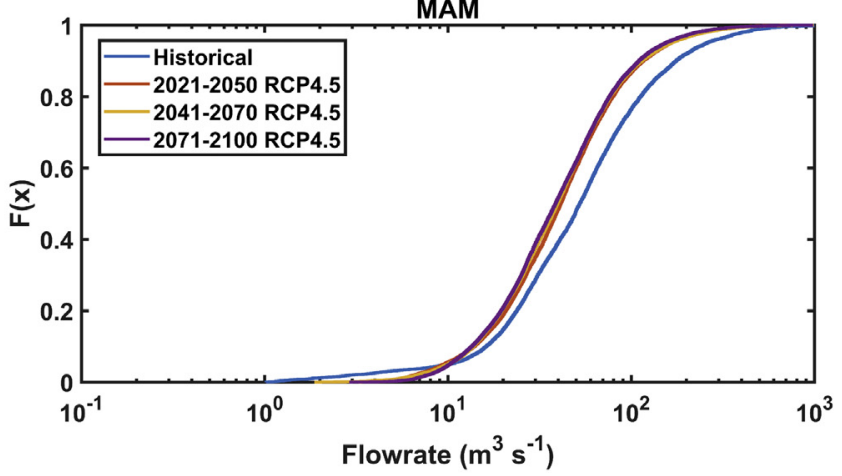

SON

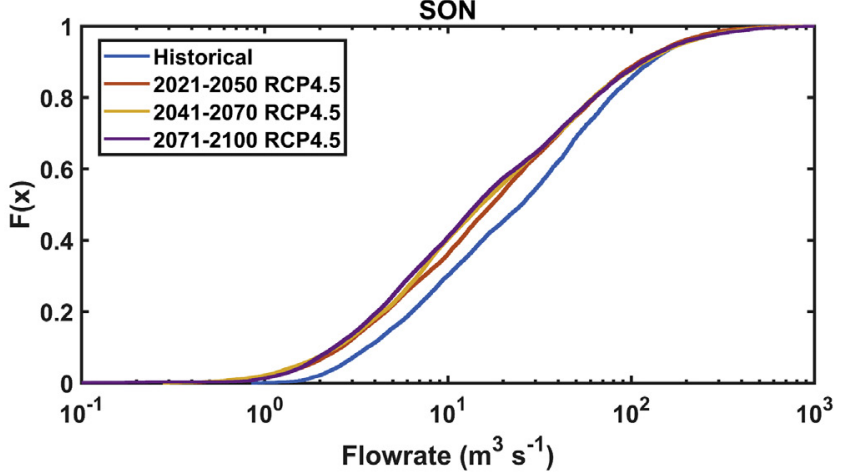

MAM

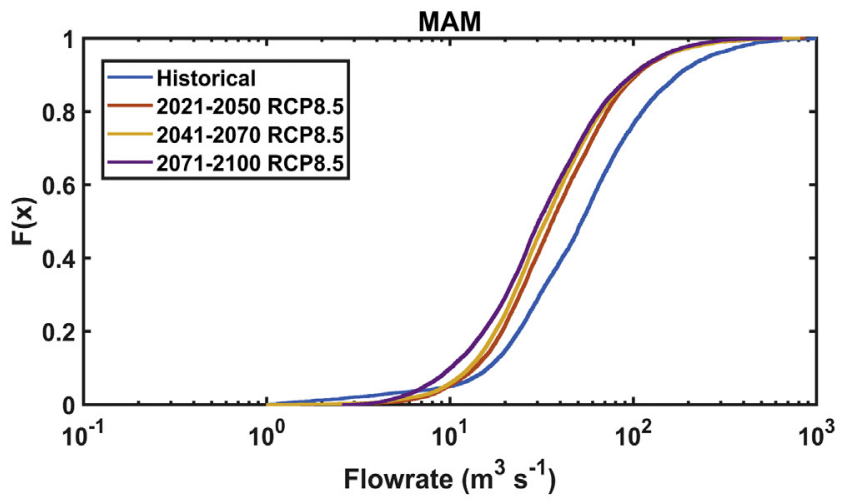

SON

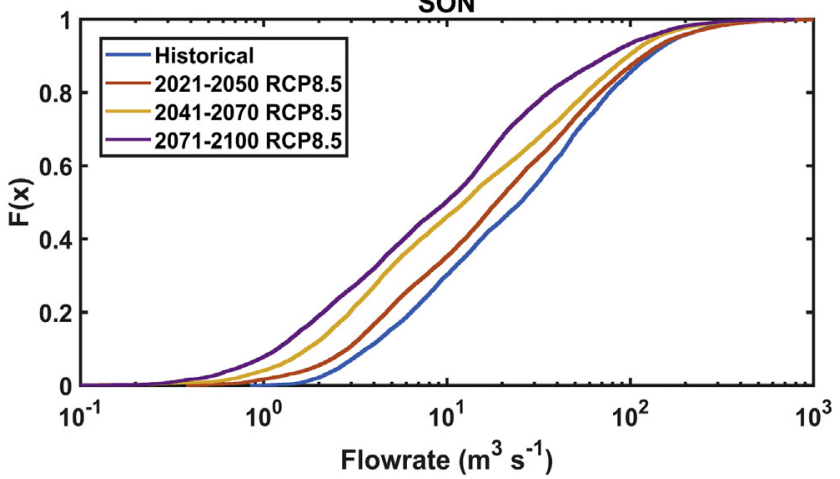

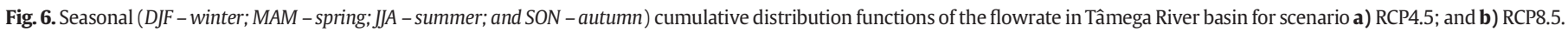

The 5-year moving averages of precipitation, evaporation, flowrate and minimum and maximum temperatures reveal low-frequency changes of these variables for both the historical and future periods (Fig. 4). The comparison between the historical and the five-member ensemble future scenarios hint at a significant decrease in the mean annual flowrate ( $-17.5 \%$ for RCP4.5 and $-27.6 \%$ for RCP8.5). Regarding the annual mean minimum and maximum temperatures and annual mean evaporation, an increase is observed for the future scenarios. Temperature increases between $10 \%$ and $22 \%$ and evaporation between $12 \%$ and $23 \%$, while annual mean precipitation shows a slight decrease over the years ( $-7 \%$ and $-13 \%$ for RCP4.5 and RCP 8.5 , respectively). Furthermore, there is a very high correlation between precipitation and flowrate, with $\mathrm{R}^{2}$ of $97 \%, 85 \%$ and $93 \%$ for baseline, RCP 4.5 and RCP8.5, respectively. The increase of evaporation is a result of increased 
Table 3

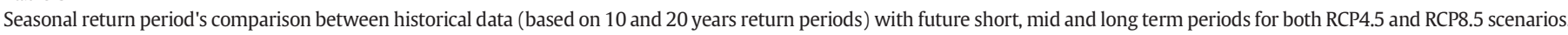

\begin{tabular}{|c|c|c|c|c|c|c|c|c|}
\hline & \multirow[t]{2}{*}{ Flowrate $\left(\mathrm{m}^{3} \mathrm{~s}^{-1}\right)$} & \multirow{2}{*}{$\frac{1950-2015}{\text { Historical }}$} & \multicolumn{2}{|c|}{$2021-2050$} & \multicolumn{2}{|c|}{$2041-2070$} & \multicolumn{2}{|c|}{$2071-2100$} \\
\hline & & & RCP4.5 & RCP8.5 & RCP4.5 & RCP8.5 & $\mathrm{RCP} 4.5$ & RCP8.5 \\
\hline \multirow[t]{2}{*}{ DJF } & 308.7 & 10 & 13 & 14 & 14 & 14 & 14 & 18 \\
\hline & 444.6 & 20 & 26 & 30 & 32 & 33 & 33 & 44 \\
\hline \multirow[t]{2}{*}{ MAM } & 175.3 & 10 & 23 & 30 & 23 & 29 & 27 & 33 \\
\hline & 257.7 & 20 & 56 & 69 & 53 & 65 & 69 & 92 \\
\hline \multirow[t]{2}{*}{ JJA } & 43.1 & 10 & 21 & 23 & 42 & 68 & 26 & 88 \\
\hline & 62.9 & 20 & 70 & 70 & 125 & 303 & 81 & 313 \\
\hline \multirow[t]{2}{*}{ SON } & 127.2 & 10 & 12 & 11 & 11 & 17 & 12 & 22 \\
\hline & 181.8 & 20 & 22 & 21 & 19 & 35 & 20 & 45 \\
\hline
\end{tabular}

temperature, with correlations of roughly $81 \%$ for the historical period and RCP4.5 and of 99\% for RCP8.5.

In order to better understand the climate change impacts on the Tâmega River basin, deviations of the monthly mean flowrates, with respect to the historical period (1950-2015), for the short-, mid- and long-term periods under RCP4.5 and RCP8.5 were assessed (Fig. 5). In an overall perspective, there is a decrease in the annual flowrates, though an increase is observed in winter, particularly in January and February, while clear downward trends are simulated for summer and autumn. These results may also reveal that extreme weather events may increase in frequency and magnitude in the future, mostly due to the projected climate change in the target river basin. Similar results were attained in other basin-scale modelling studies of climate change impacts on hydrology (Krysanova et al., 2017; Liuzzo et al., 2009; Praskievicz and Chang, 2009; Skoulikaris and Ganoulis, 2011; Yu and Wang, 2009). All of these studies report increases of winter and early spring runoffs, accompanied by decreases in summer runoff, except for basins were massive snowmelt is synchronized with late spring flowrate peaks (Cunderlik and Simonovic, 2005; Eckhardt and Ulbrich, 2003; Loukas et al., 2002).

To better highlight the differences in flowrates among periods and scenarios, cumulative distribution functions for each season (DJF - winter; MAM - spring; JJA - summer; SON - autumn) were computed separately (Fig. 6). The differences in flowrates between seasons under both RCPs are particularly noticeable, especially in summer and autumn. While RCP4.5 shows little difference in winter and spring flowrates, the differences are more noticeable in RCP8.5. For further details on the changes in the distributions, the respective histograms can also be found in supplementary material (Fig. S2).

The two-sample Lilliefors (Kolmogorov-Smirnov) test applied to the daily flowrate distributions shows statistically significant changes, at 99\% confidence level, in the distributions for all seasons, periods and scenarios. In fact, in a climate change scenario, the Tâmega River hydrology will undergo considerable changes, which can also be modified as a result of land cover changes that were not addressed herein, owing to the complexity of multiple feedback mechanisms that cannot be incorporated in our modelling approach.

The flowrates corresponding to specific return periods were calculated for all seasons and scenarios based on these empirical distributions (Table 3 ). Starting with the estimation of the flowrates corresponding to 10 and 20-year return periods for the historical period and for each season separately, the new return periods associated with these same flowrates were calculated for the future. Overall, significant differences are observed for the 10-year return period in winter and autumn, with higher return periods for scenario RCP8.5 for the long term period (2071-2100). The highest difference is observed in summer: the 20-year return period is historically associated with a flowrate of ca. $62.9 \mathrm{~m}^{3} \mathrm{~s}^{-1}$, whereas it corresponds to a return period of 313 years in 2071-2100 under RCP8.5, i.e. a much rarer event than today. These findings show that, in the future, water availability in summer may be a real concern regarding water security in the Tâmega River basin.

\section{Conclusions}

In the present study, the spatial-temporal changes of hydrological and meteorological variables and the linkage between surface runoff and precipitation/temperature over the Tâmega River basin were analyzed. The use of an integrated watershed model (HSPF), enabled assessing the impact of climate change on hydrology. The study was carried out for historical (1950-2015) and future (2021-2100) periods under two different Representative Concentration Pathways (RCP4.5 and RCP8.5). The impacts of precipitation and temperature on the hydrology of the target river basin were quantified through existing climatic databases for the historical period (Belo-Pereira et al., 2011; Fonseca and Santos, 2018a) and an ensemble of 5 EURO-CORDEX model simulations for the future periods and scenarios. The HSPF hydrological model was coupled with the climatic data in order to transfer climatic information into hydrological information, namely daily flowrates.

The annual precipitation over the Tâmega River basin exhibit weakly decreasing trends across the entire future period. Temperatures, on the other hand, show consistently warming trends throughout the basin for the future period, with a mean warming rate of $0.03^{\circ} \mathrm{C}$ per year for maximum temperature (TX) and of $0.01{ }^{\circ} \mathrm{C}$ per year for minimum temperature (TN). As a result, the mean annual flowrate decreased at all hydrometric stations by about $0.25 \mathrm{~m}^{3} \mathrm{~s}^{-1}$ per year, with increased flowrates in winter when compared to the historical period, but significantly lower flowrates in summer. This will most likely result in higher probabilities of summertime droughts and higher risks of wintertime floods in the future. The results achieved here were also reported in similar basin-scale modelling studies of impacts of climate change on hydrology (Krysanova et al., 2017; Liuzzo et al., 2009; Skoulikaris and Ganoulis, 2011; Thorne, 2011; Yu and Wang, 2009).

There are several sources of uncertainty in both climate (Hattermann et al., 2015), and hydrological (Bosshard et al., 2013; Gädeke et al., 2014; Ott et al., 2013; Vetter et al., 2015) models. Thus, the outcomes of this study ought to be considered as indicative of the expected future, providing guidelines rather than accurate predictions. Land use changes were not considered in the hydrological simulations, though they may also play a key role in the future flowrate conditions. Still, future water resources availability in the catchment may be under strong pressure to meet water security in the region under climate change, particularly during the dry season (summer half of the year). In spite of all the inherent uncertainties to the modelling process, it is crucial to be aware of the effects of climate change on water resources, as well as of the impacts these changes may have on the management and planning of future water resources. Although the present study findings refer to a specific watershed, they may be largely extrapolated to other watersheds in Portugal, in Southern Europe and in the Mediterranean basin, as the climate change projections for this region hint at pronounced warming and drying trends, mainly in the summer half of the year (typical Mediterranean climate behaviour). This study is therefore archetypal of other basin-scale studies under similar climate change threats. 


\section{Acknowledgments}

This study was funded by the "Integrative Research in Environment, Agro-Chains and Technology" project (INTERACT; NORTE-010145FEDER-000017) in its line of research entitled BEST-T4, co-financed by the European Regional Development Fund (ERDF) through NORTE 2020 (North Regional Operational Program 2014/2020). It was also supported by FEDER/COMPETE/POCI (Operational Competitiveness and Internationalization Programme), POCI-01-0145-FEDER-006958, and by FCT (Portuguese Foundation for Science and Technology), UID/AGR/ 04033/2019.

\section{Appendix A. Supplementary data}

Supplementary data to this article can be found online at https://doi. org/10.1016/j.scitotenv.2019.01.435.

\section{References}

Ali, G., 2018. Climate change and associated spatial heterogeneity of Pakistan: empirical evidence using multidisciplinary approach. Sci. Total Environ. 634, 95-108.

Andrade, C., Santos, J.A., Pinto, J.G., Corte-Real, J., 2011. Large-scale atmospheric dynamics of the wet winter 2009-2010 and its impact on hydrology in Portugal. Clim. Res. 46, 29-41.

Andréasson, J., Bergström, S., Carlsson, B., Graham, L.P., Lindström, G., 2004. Hydrological change-climate change impact simulations for Sweden. AMBIO J. Hum. Environ. 33 228-234.

Bae, D.-H., Jung, I.W., Chang, H., 2008. Potential changes in Korean water resources estimated by high-resolution climate simulation. Clim. Res. 35, 213-226.

Belo-Pereira M, Dutra E, Viterbo P. Evaluation of global precipitation data sets over the Iberian Peninsula. J. Geophys. Res.: Atmospheres 2011; 116.

Bergman, M., Green, W., Donnangelo, L., 2002. Calibration of storm loads in the South Prong Watershed, Florida, using Basins/HSPF 1. J. Am. Water Resour. Assoc. 38 $1423-1436$

Bicknell, B.R., 2000. Basins Technical Note 6: Estimating Hydrology and Hydraulic Parameters for HSPF. US: Environmental Protection Agency Google Scholar.

Bicknell, B.R., Imhoff, J.C., Kittle Jr., J.L., Jobes, T.H., Donigian Jr., A.S., Johanson, R., 2001. Hydrological Simulation Program-Fortran: HSPF Version 12 User's Manual. AQUA TERRA Consultants. Mountain View, California.

Bosshard, T., Carambia, M., Goergen, K., Kotlarski, S., Krahe, P., Zappa, M., et al., 2013. Quantifying uncertainty sources in an ensemble of hydrological climate-impact projections. Water Resour. Res, 49, 1523-1536.

Boughariou, E., Allouche, N., Jmal, I., Mokadem, N., Ayed, B., Hajji, S., et al., 2018. Modeling aquifer behaviour under climate change and high consumption: case study of the Sfax region, southeast Tunisia. J. Afr. Earth Sci. 141, 118-129.

Bronstert, A., 2003. Floods and climate change: interactions and impacts. Risk Anal. 23 545-557.

Christensen, N.S., Wood, A.W., Voisin, N., Lettenmaier, D.P., Palmer, R.N., 2004. The effects of climate change on the hydrology and water resources of the Colorado River basin. Clim. Chang. 62, 337-363.

Costa, M.H., Botta, A., Cardille, J.A., 2003. Effects of large-scale changes in land cover on the discharge of the Tocantins River, Southeastern Amazonia. J. Hydrol. 283, 206-217.

Crawford, N.H., Linsley, R.K., 1966. Digital Simulation in Hydrology'Stanford Watershed Model 4.

Crosbie, R.S., Scanlon, B.R., Mpelasoka, F.S., Reedy, R.C., Gates, J.B., Zhang, L., 2013. Potential climate change effects on groundwater recharge in the High Plains Aquifer, USA. Water Resour. Res. 49, 3936-3951.

Cunderlik, J.M., Simonovic, S.P., 2005. Hydrological extremes in a southwestern Ontario river basin under future climate conditions/Extrêmes hydrologiques dans un basin versant du sud-ouest de l'Ontario sous conditions climatiques futures. Hydrol. Sci. J. 50.

Donigian, A.S., Crawford, N.H., 1976. Modeling nonpoint pollution from the land surface: US Environmental Protection Agency, Office of Research and Development. Environmental Research Laboratory (EPA-600/3-76-083).

Donigian AS, Davis HH. User's Manual for Agricultural Runoff Management(ARM) Model. Available from the National Technical Information Service, Springfield VA 22161 as PB-286 366, Price codes: A 08 in paper copy, A 01 in microfiche. Report 1978.

Donigian AS, Huber WC. Modeling of nonpoint source water quality in urban and nonurban areas: Environmental Research Laboratory, Office of Research and Development, US Environmental Protection Agency, 1991.

Donigian Jr A, Bicknell B, Imhoff J. Hydrological simulation program-FORTRAN Chapter 12. Computer models of watershed hydrology. Water Resources. Publ., Highland Ranch, CO 1995.

Eckhardt, K., Ulbrich, U., 2003. Potential impacts of climate change on groundwater recharge and streamflow in a central European low mountain range. J. Hydrol. 284, 244-252.

Eisenreich, S.J., Bernasconi, C., Campostrini, P., 2005. Climate Change and the European Water Dimension.

Fonseca, A., Santos, J., 2018a. High-resolution temperature datasets in Portugal from a geostatistical approach: variability and extremes. J. Appl. Meteorol. Climatol. 57, 627-644.
Fonseca, A., Santos, J., 2018b. A new very high-resolution climatological dataset in Portugal: application to hydrological modeling in a mountainous watershed. Phys. Chem. Earth (Parts A/B/C)

Fonseca, A., Ames, D.P., Yang, P., Botelho, C., Boaventura, R., Vilar, V., 2014. Watershed model parameter estimation and uncertainty in data-limited environments. Environ. Model. Softw. 51, 84-93.

Fonseca, A., Botelho, C., Boaventura, R., Vilar, V., 2015. Global warming effects on faecal coliform bacterium watershed impairments in Portugal. River Res. Appl. 31, 1344-1353.

Fonseca, A., Fernandes, L.S., Fontainhas-Fernandes, A., Monteiro, S., Pacheco, F., 2016. From catchment to fish: impact of anthropogenic pressures on gill histopathology. Sci. Total Environ. 550, 972-986.

Fonseca, A., Boaventura, R.A., Vilar, V.J., 2018a. Integrating water quality responses to best management practices in Portugal. Environ. Sci. Pollut. Res. 25, 1587-1596.

Fonseca, A., Santos, M., Santos, J., 2018b. Hydrological and flood hazard assessment using a coupled modelling approach for a mountainous catchment in Portugal. Stoch. Env. Res. Risk A. 1-13.

Fraga, H., García de Cortázar Atauri, I., Santos, J.A., 2018. Viticultural irrigation demands under climate change scenarios in Portugal. Agric. Water Manag. 196, 66-74.

Frei, A., Armstrong, R.L., Clark, M.P., Serreze, M.C., 2002. Catskill Mountain water resources: vulnerability, hydroclimatology, and climate-change sensitivity. Ann. Assoc. Am. Geogr. 92, 203-224.

Fujihara, Y., Tanaka, K., Watanabe, T., Nagano, T., Kojiri, T., 2008. Assessing the impacts of climate change on the water resources of the Seyhan River Basin in Turkey: use of dynamically downscaled data for hydrologic simulations. J. Hydrol. 353, 33-48.

Gädeke, A., Hölzel, H., Koch, H., Pohle, I., Grünewald, U., 2014. Analysis of uncertainties in the hydrological response of a model-based climate change impact assessment in a subcatchment of the Spree River, Germany. Hydrol. Process. 28, 3978-3998.

Gebre, S., Tadele, K., Mariam, B., 2015. Potential impacts of climate change on the hydrology and water resources availability of Didessa Catchment, Blue Nile River Basin, Ethiopia. J. Geol. Geosci. 4, 193

Ghaffari, G., Keesstra, S., Ghodousi, J., Ahmadi, H., 2010. SWAT-simulated hydrological impact of land-use change in the Zanjanrood basin. Northwest Iran. Hydrological Processes: An International Journal 24, 892-903.

Gibelin, A.-L., Déqué, M., 2003. Anthropogenic climate change over the Mediterranean region simulated by a global variable resolution model. Clim. Dyn. 20, 327-339.

Giorgi, F., Lionello, P., 2008. Climate change projections for the Mediterranean region. Glob. Planet. Chang. 63, 90-104.

Graham, L.P., 2004. Climate change effects on river flow to the Baltic Sea. AMBIO J. Hum. Environ. 33, 235-241.

Haas, L., December 2002. Mediterranean water resources planning and climate change adaptation. Contribution to the Water, Wetlands and Climate Change Mediterranean Regional Roundtable, Athens, pp. 10-11.

Hattermann, F., Gömann, H., Conradt, T., Kaltofen, M., Kreins, P., Wechsung, F., 2007. Impacts of global change on water-related sectors and society in a trans-boundary central European river basin? Part 1: project framework and impacts on agriculture. Adv. Geosci. 11, 85-92.

Hattermann, F.F., Post, J., Conradt, T., Wechsung, F., 2008. Assessment of water availability in a Central-European River Basin (Elbe) under climate change. 气候变化研究进展 4, $42-50$.

Hattermann, F.F., Huang, S., Koch, H., 2015. Climate change impacts on hydrology and water resources. Meteorol. Z. 24, 201-211.

Haylock, M., Hofstra, N., Tank, A.K., Klok, E., Jones, P., New, M., 2008. A European daily high-resolution gridded data set of surface temperature and precipitation for 1950-2006. J. Geophys. Res.-Atmos. 113.

Hummel, P., Kittle Jr., J., Gray, M., 2001. WDMUtil-A Tool for Managing Watershed Modeling Time-series Data: User's Manual. US EPA Office of Water, Washington DC.

IPCC, 2007a. Climate Change 2007: Impacts, Adaptation, and Vulnerability. Contribution of Working Group II to the Third Assessment Report of the Intergovernmental Panel on Climate Change.

IPCC, 2007b. Climate change 2007: the physical science basis. Contribution of Working Group I to the Fourth Assessment Report of the Intergovernmental Panel on Climate Change.

IPCC, 2013. Climate Change 2013: The Physical Science Basis - Summary for Policymakers. Contribution of Working Group I to the Fifth Assessment Report of the Intergovernmental Panel on Climate Change. - Intergovernmental Panel on Climate Change. IPCC Secretariat.

IPCC, 2014. Working Group II: Impacts, Adaptation and Vulnerability.

Kabat, P., Schulze, R., Hellmuth, M.E., Veraart, J.A., 2003. Coping With Impacts of Climate Variability and Climate Change in Water Management: A Scoping Paper: International Secretariat of the Dialogue on Water and Climate Wageningen.

Kling, H., Fuchs, M., Paulin, M., 2012. Runoff conditions in the upper Danube basin under an ensemble of climate change scenarios. J. Hydrol. 424, 264-277.

Kohler, M., Nordenson, T., Fox, W., 1955. Evaporation From Pans and Lakes: US Weather Bureau Research Paper 38. US Weather Bureau, Washington, DC.

Krysanova, V., Vetter, T., Hattermann, F., 2008. Detection of change in drought frequency in the Elbe basin: comparison of three methods. Hydrol. Sci. J. 53, 519-537.

Krysanova, V Vetter, T, Eisner, S, Huang S, Pechlivanidis, I, Strauch, M, et al, 2017. Intercomparison of regional-scale hydrological models and climate change impacts projected for 12 large river basins worldwide-a synthesis. Environ. Res. Lett. 12, 105002.

Liuzzo, L, Noto, L.V., Vivoni, E.R., La Loggia, G., 2009. Basin-scale water resources assessment in Oklahoma under synthetic climate change scenarios using a fully distributed hydrologic model. J. Hydrol. Eng. 15, 107-122.

Loizidou, M., Giannakopoulos, C., Bindi, M., Moustakas, K., 2016. Climate Change Impacts and Adaptation Options in the Mediterranean Basin. Springer. 
Loukas, A., Vasiliades, L., Dalezios, N.R., 2002. Potential climate change impacts on flood producing mechanisms in southern British Columbia, Canada using the CGCMA1 simulation results. J. Hydrol. 259, 163-188.

Me, W., Hamilton, D.P., McBride, C.G., Abell, J.M., Hicks, B.J., 2018. Modelling hydrology and water quality in a mixed land use catchment and eutrophic lake: effects of nutrient load reductions and climate change. Environ. Model. Softw. 109, 114-133.

Mirza, M.M.Q., 2003. Climate change and extreme weather events: can developing countries adapt? Clim. Pol. 3, 233-248.

Mortazavi-Naeini, M., Kuczera, G., Kiem, A.S., Cui, L., Henley, B., Berghout, B., et al., 2015. Robust optimization to secure urban bulk water supply against extreme drought and uncertain climate change. Environ. Model. Softw. 69, 437-451.

Mourato, S., Moreira, M., Corte-Real, J., 2014. Xe. Water availability in southern Portugal for different climate change scenarios subjected to bias correction. J. Urban Environ. Eng. 8, 109-117.

Nash, J.E., Sutcliffe, J.V., 1970. River flow forecasting through conceptual models part I-a discussion of principles. J. Hydrol. 10, 282-290.

Nicholls, N., Gruza, G., Jouzel, J., Karl, T., Ogallo, L., Parker, D., 1996. Observed Climate Variability and Change. Cambridge University Press Cambridge.

Ott, I., Duethmann, D., Liebert, J., Berg, P., Feldmann, H., Ihringer, J., et al., 2013. Highresolution climate change impact analysis on medium-sized river catchments in Germany: an ensemble assessment. J. Hydrometeorol. 14, 1175-1193.

Penman, H.L., 1948. Natural evaporation from open water, bare soil and grass. Proc. R. Soc. Lond. A 193, 120-145.

Pervez, M.S., Henebry, G.M., 2015. Assessing the impacts of climate and land use and land cover change on the freshwater availability in the Brahmaputra River basin. J. Hydrol. 3, 285-311.

Praskievicz, S., Chang, H., 2009. A review of hydrological modelling of basin-scale climate change and urban development impacts. Prog. Phys. Geogr. 33, 650-671.

Sahin, V., Hall, M.J., 1996. The effects of afforestation and deforestation on water yields. J. Hydrol. 178, 293-309.

Santos, J.A., Costa, R., Fraga, H., 2018. New insights into thermal growing conditions of Portuguese grapevine varieties under changing climates. Theor. Appl. Climatol. 1-12.

Santos, J.F., Pulido-Calvo, I., Portela, M.M., 2010. Spatial and temporal variability of droughts in Portugal. Water Resour. Res. 46.

Santos, M., Fragoso, M., Santos, J.A., 2017. Regionalization and susceptibility assessment to daily precipitation extremes in mainland Portugal. Appl. Geogr. 86, 128-138.
Skoulikaris, C., Ganoulis, J., 2011. Assessing climate change impacts at river basin scale by integrating global circulation models with regional hydrological simulations. Eur. Water 34, 53-60.

Slingo, J., Palmer, T., 2011. Uncertainty in weather and climate prediction. Phil. Trans. R. Soc. A 369, 4751-4767.

Solomon, S., Plattner, G.-K., Knutti, R., Friedlingstein, P., 2009. Irreversible climate change due to carbon dioxide emissions. Proc. Natl. Acad. Sci. 106, 1704-1709.

Thodsen, H., 2007. The influence of climate change on stream flow in Danish rivers. J. Hydrol. 333, 226-238.

Thorne, R., 2011. Uncertainty in the impacts of projected climate change on the hydrology of a subarctic environment: Liard River Basin. Hydrol. Earth Syst. Sci. 15, 1483-1492.

Todd, M.C., Taylor, R., Osborn, T., Kingston, D., Arnell, N., Gosling, S., 2011. Uncertainty in climate change impacts on basin-scale freshwater resources-preface to the special issue: the QUEST-GSI methodology and synthesis of results. Hydrol. Earth Syst. Sci. $15,1035-1046$.

Varis, O., Kajander, T., Lemmelä, R., 2004. Climate and water: from climate models to water resources management and vice versa. Clim. Chang. 66, 321-344.

Vetter, T., Huang, S., Aich, V., Yang, T., Wang, X., Krysanova, V., et al., 2015. Multi-mode climate impact assessment and intercomparison for three large-scale river basins on three continents. Earth Syst. Dyn. 6.

Vrzel, J., Ludwig, R., Gampe, D., Ogrinc, N., 2019. Hydrological system behaviour of an alluvial aquifer under climate change. Sci. Total Environ. 649, 1179-1188.

Wagena, M.B., Collick, A.S., Ross, A.C., Najjar, R.G., Rau, B., Sommerlot, A.R., et al., 2018. Impact of climate change and climate anomalies on hydrologic and biogeochemical processes in an agricultural catchment of the Chesapeake Bay watershed, USA. Sci. Total Environ. 637-638, 1443-1454.

Whitehead, P.G., Jin, L., Macadam, I., Janes, T., Sarkar, S., Rodda, H.J.E., et al., 2018. Modelling impacts of climate change and socio-economic change on the Ganga, Brahmaputra, Meghna, Hooghly and Mahanadi river systems in India and Bangladesh. Sci. Total Environ. 636, 1362-1372.

Yang, C., Fraga, H., Van Ieperen, W., Santos, J.A., 2018. Modelling climate change impacts on early and late harvest grassland systems in Portugal. Crop Pasture Sci. 69, 821-836.

Yu, P.S., Wang, Y.C., 2009. Impact of climate change on hydrological processes over a basin scale in northern Taiwan. Hydrol. Process. 23, 3556-3568.

Zhang, J., Ross, M., Trout, K., Zhou, D., 2009. Calibration of the HSPF model with a new coupled FTABLE generation method. Prog. Nat. Sci. 19, 1747-1755. 